\title{
ANALISIS PERBEDAAN ABNORMAL RETURN DAN TRADING VOLUME ACTIVITY SEBELUM DAN SESUDAH PERISTIWA PENETAPAN UNDANG-UNDANG TAX AMNESTY
}

\section{Komang Wisnu Wardhana1, Hermanto², I Nyoman Nugraha AP3}

\author{
${ }^{1}$ Master of Management Program, Mataram University, Indonesia. \\ E-mail : komangwisnu3@gmail.com \\ 2,3Faculty of Economics and Business, Mataram University, Indonesia \\ 2hermanto57@gmail.com \\ 3nyoman.nugraha@unram.ac.id
}

\begin{tabular}{|c|c|}
\hline ARTICLE INFO & ABSTRACT \\
\hline $\begin{array}{l}\text { Keywords: } \\
\text { Abnormal Return, Trading Volume } \\
\text { Activity, Tax Amnesty } \\
\text { Kata Kunci: } \\
\text { Pengembalian Tidak Normal, Volume } \\
\text { Perdagangan Saham, Pengampunan Pajak } \\
\text { How to cite: } \\
\text { Wisnu Wardhana, I Komang., Hermanto., } \\
\text { Nugraha AP, I Nyoman., (2021). Analisis } \\
\text { Perbedaan Abnormal Return Dan Trading } \\
\text { Volume Activity Sebelum Dan Sesudah } \\
\text { Peristiwa Penetapan Undang-Undang Tax } \\
\text { Amnesty. JMM UNRAM, 10(3),186-198 } \\
\text { DOI: } \quad \text { : 1 September 2021 } \\
\text { https://doi.org/10.29303/jmm.v10i3.661 } \\
\text { Dikumpulkan : 17 Agustus 2021 } \\
\text { Direvisi } \\
\text { Dipublikasi September 2021 }\end{array}$ & $\begin{array}{l}\text { The purpose of this study was to determine the } \\
\text { difference in the average abnormal return and trading } \\
\text { volume activity before and after the enactment of the tax } \\
\text { amnesty law on the LQ-45 index. The type of data used in } \\
\text { this study is secondary data with data collection techniques } \\
\text { using the documentation method. Determination of the } \\
\text { sample in this study using purposive sampling method with } \\
\text { certain criteria so as to obtain } 45 \text { samples. The analytical } \\
\text { technique used in this research is paired sample t-test with } \\
\text { an observation period of } 10 \text { days. The results of this study } \\
\text { indicate that: (1) There is no difference in the average } \\
\text { abnormal return before and after the enactment of the tax } \\
\text { amnesty law. (2) There is no difference in the average } \\
\text { trading volume activity before and after the enactment of } \\
\text { the tax amnesty law. } \\
\text { Tujuan penelitian ini adalah untuk mengetahui } \\
\text { perbedaan rata-rata abnormal return dan trading volume } \\
\text { activity sebelum dan setelah penetapan undang-undang tax } \\
\text { amnesty pada indeks LQ-45. Jenis data yang digunakan dalam } \\
\text { penelitian ini adalah data sekunder dengan teknik } \\
\text { pengumpulan data menggunakan metode dokumentasi. } \\
\text { Penentuan sampel dalam penelitian ini menggunakan metode } \\
\text { purposive sampling dengan kriteria-kriteria tertentu sehingga } \\
\text { memperoleh } 45 \text { sampel. Teknik analisis yang digunakan dalam } \\
\text { penelitian ini adalah paired sample t-test dengan periode } \\
\text { pengamatan selama 10 hari. Hasil penelitian ini menunjukkan } \\
\text { bahwa: (1) Tidak terdapat perbedaan rata-rata abnormal return } \\
\text { sebelum dan setelah penetapan UU tax amnesty. (2) Tidak } \\
\text { terdapat perbedaan rata-rata trading volume activity sebelum } \\
\text { dan setelah penetapan UU tax amnesty. }\end{array}$ \\
\hline
\end{tabular}




\section{PENDAHULUAN}

Pembangunan nasional tidak terlepas dari sumber pendapatan negara yang disebut sebagai pajak. Menurut undang-undang Nomor 6 Tahun 1983 Tentang Ketentuan Umum dan Tata Cara Perpajakan sebagaimana telah diubah terakhir dengan Undang - Undang Nomor 16 tahun 2009 dalam pasal 1 berbunyi bahwa pajak adalah kontribusi wajib kepada negara yang terutang oleh orang pribadi atau badan yang bersifat memaksa berdasarkan Undang - Undang dengan tidak mendapatkan imbalan secara langsung dan digunakan untuk keperluan negara bagi sebesar-besarnya untuk kemakmuran rakyat. Oleh sebab itu pajak memiliki peran yang sangat vital dalam sebuah negara karena tanpa pajak maka pembangunan nasional suatu bangsa tidak dapat berjalan dengan baik.

Menurut data BPS pertumbuhan perekonomian Indonesia pada tahun 2010 merupakan yang tertinggi 6,81 persen, kemudian berturut - turut menurun dari 6,44 persen pada tahun 2011, tahun 2012 sebesar 6,19 persen, tahun 2013 sebesar 5,56 persen, tahun 2014 sebesar 5,02 persen dan pada tahun 2015 sebesar 4,79 persen. Angka pertumbuhan ekonomi pada tahun 2015 merupakan yang terendah sejak 5 tahun terakhir (www.bps.go.id), harga komoditas dan perdagangan dunia anjlok menyebabkan kinerja ekspor Indonesia jatuh ke titik nadir, begitu pula investasi asing langsung (foreign direct investment/FDI) yang menyebabkan lesunya perekonomian akhirnya berdampak pada kinerja perusahaan di berbagai sektor.

Pendapatan perusahaan yang menurun tentu mempengaruhi pajak yang mereka bayar. Dampaknya adalah perlambatan ekonomi Indonesia, defisit neraca perdagangan, defisit anggaran membesar, dan penurunan laju pertumbuhan sektor industri/manufaktur. Upaya pemerintah dalam mendorong pertumbuhan ekonomi Indonesia yaitu salah satunya dengan mengoptimalkan penerimaan pajak bagi negara untuk membiayai pembangunan nasional agar pertumbuhan domestik meningkat. Salah satu cara yang ditempuh adalah melalui pemberlakukan program pengampunan pajak (PPP) atau tax amnesty, yaitu sebuah program yang dilaksanakan dalam periode waktu tertentu untuk memberikan kesempatan kepada wajib pajak melunasi pajak terutang yang belum dibayar dan/atau pajak yang seharusnya terutang, dengan memberikan kompensasi berupa pembebasan dari sanksi (bunga maupun denda) dan tuntutan pidana (Widihartanto \& Herru, 2016).

Pemerintah mengeluarkan progam pengampunan pajak atau tax amnesty sebagai upaya untuk dapat menambah kas negara dan pada akhirnya mendorong pertumbuhan ekonomi, yang bertujuan untuk peningkatan likuiditas domestik, perbaikan nilai tukar rupiah, suku bunga yang kompetitif, dan peningkatan investasi dalam negeri yang bertujuan untuk memacu pertumbuhan ekonomi melalui repatriasi aset para wajib pajak yang belum dilaporkan kepada negara. Bagi 


\section{NATIONALLY ACCREDITED JOURNAL - DEECREE NO. 21/E/RRPT/2O18}

Indonesia sendiri tax amnesty bukanlah barang baru karena dalam catatan sejarah pemerintah Indonesia pernah memberlakukan kebijakan tax amnesty dua kali yakni masing - masing pada tahun 1964 dan 1984.

Pemerintah yang melihat peluang tersebut sebagai sumber penerimaan negara untuk mendukung pembangunan nasional telah mengeluarkan kebijakan melalui keputusan Presiden dengan kajian mendalam hingga membuat peraturan perundang-undangan yang disebut sebagai Program Pengampunan Pajak atau Tax Amnesty yang diatur melalui UU No.11 Tahun 2016 yang disahkan oleh DPR dan Presiden Jokowi yang mulai berlaku sejak tanggal 28 Juni 2016 yang menandakan dimulainya program tersebut. Dengan demikian, diharapkan para wajib pajak yang sebelumnya belum maksimal melaporkan hartanya baik di dalam maupun yang ada di luar negeri dapat memanfaatkan program tersebut dengan menarik dananya dari luar negeri ke dalam negeri melalui pilihan - pilihan investasi yang ditawarkan pemerintah dalam rangka mendukung pembangunan nasional dan menambah sumber pendapatan negara melalui uang tebusan pajak.

Salah satu pilihan investasi para WNI yang hartanya ditarik dari luar negeri maupun yang dilaporkan di dalam negeri yaitu di pasar modal. Pasar modal merupakan salah satu instrumen perekonomian yang mempertemukan modal dari pihak yang kelebihan dana (investor) dengan pihak yang membutuhkan dana. Peristiwa yang mempengaruhi pasar modal pada prinsipnya mengandung suatu informasi. Kandungan informasi yang diserap oleh pasar akan digunakan oleh para investor untuk menentukan keputusan investasinya, sehingga investor akan berupaya mendapatkan informasi yang lengkap dan akurat. Jika pasar bereaksi dengan cepat dan akurat untuk mencapai harga keseimbangan baru yang sepenuhnya mencerminkan informasi yang tersedia, maka kondisi pasar seperti itu disebut dengan pasar yang efisien (Hartono, 2010).

Informasi sebagai salah satu dasar investor dalam pengambilan keputusan investasi di pasar modal dapat memberikan dampak positif apabila informasi yang diterima adalah informasi baik (good news) dan sebaliknya akan memberikan dampak negatif apabila informasi yang diterima adalah informasi tersebut buruk (bad news) akan menyebabkan suatu harga saham mengalami penurunan. Informasi yang berasal dari faktor internal perusahan maupun faktor eksternal seperti kebijakan pemerintah sangat mempengaruhi harga saham suatu perusahaan, atau secara umum dalam pasar modal disebut sebagai IHSG (Indeks Harga Saham Gabungan) yang merupakan gabungan dari seluruh emiten yang terdafatar di BEI (Bursa Efek Indonesia) dan bisa juga dari indikator LQ-45 adalah perhitungan dari 45 saham, yang diseleksi melalui beberapa kriteria pemilihan dan memiliki tingkat likuiditas yang tinggi. Selain penilaian atas likuiditas, seleksi atas saham-saham tersebut mempertimbangkan kapitalisasi pasar. Informasi IHSG dan indeks LQ-45 pada saat penetapan UU Tax Amnesty oleh DPR yang terjadi pada tanggal 28 Juni 2016 terjadi pada hari Selasa dan IHSG pada tanggal tersebut ditutup pada posisi 4.882,171 poin sedangkan LQ-45 pada posisi 833,85 poin (www.idx.co.id). 


\section{NATIONALLY ACCREDITED JOURNAL - DEECREE NO. 21/E/RRPT/2O18}

Penelitian tentang Tax Amnesty dilakukan oleh Rahayu, (2016) yang menunjukkan hasil nilai tidak signifikan yang artinya kebijakan tax amnesty tidak

memberikan abnormal return pada saham-saham syariah yang masuk JII dan menunjukkan tidak terdapat perbedaan yang signifikan reaksi pasar terhadap tax amnesty. Adapun penelitian yang dilakukan Gesit (2016) denga hasi uji beda rata-rata yang dilakukan atas average abnormal return terdapat perbedaan yang signifikan average abnormal return sebelum dan setelah peristiwa kebijakan moneter yang ditetapkan oleh Bank Sentral. Sedangkan Rachman ( 2013 ) dengan hasil penelitian menunjukan pengumuman penetapan calon pasangan presiden dan wakil presiden oleh KPU, memberikan pengaruh yang signifikan terhadap perubahan harga saham di BEI, sehingga dapat digunakan sebagai indikator untuk menentukan reaksi pasar bursa saham di Indonesia. Nugroho ( 2013 ) menyatakan bahwa selama periode peristiwa tsunami Jepang 2011 tidak ditemukan perbedaan rata-rata abnormal return sebelum dan sesudah peristiwa dan aktivitas volume perdagangan juga tidak ditemukan perbedaan sebelum dan sesudah peristiwa. Sementara Sirait, Tiswiyanti, \& Mansur, (2012) menyatakan bahwa terdapat perbedaan Average Abnormal Return (AAR) yang signifikan sebelum dan setelah perisitiwa pergantian Menteri Keuangan tahun 2010 pada perusahaan perbankan. Wardhani (2012) menemukan bukti empiris bahwa terdapat abnormal return dan trading volume activity bernilai positif signifikan pada beberapa hari di sekitar tanggal peristiwa peristiwa politik dalam negeri yaitu Pemilihan Gubernur DKI Jakarta Putaran II 2012. Saragih (2011) menunjukkan bahwa terjadi abnormal return yang signifikan saat sebelum dan setelah peristiwa kasus century dan tidak ada perbedaan volume perdagangan sebelum dan sesudah peristiwa kasus century.

Oleh karena itu dari penjelasan diatas dapat di asumsikan bahwa kebijakan tax amnesty seharusnya memberikan sentiment positif (good news) di dunia investasi khususnya di pasar modal, dan untuk melihat bagaimana reaksi harga saham khususnya LQ-45 terhadap kebijakan tax amnesty dengan melihat ada tidaknya abnormal return dan trading volume activity. Dengan adanya fenomena seperti yang dikemukakan di atas, penulis melakukan penelitian yang berkaitan dengan studi peristiwa tentang analisis perbedaan abnormal return dan trading volume activity sebelum dan sesudah peristiwa penetapan RUU Pengampunan Pajak menjadi UU.

\section{KAJIAN PUSTAKA}

\section{$2.1 \quad$ Event Study}

Studi peristiwa (event study) merupakan studi yang mempelajari reaksi pasar terhadap suatu peristiwa (event) yang informasinya dipublikasikan sebagai suatu pengumuman. Event Study dapat digunakan untuk menguji kandungan informasi (Information Content) dari suatu pengumuman dan dapat juga digunakan untuk menguji efisiensi pasar (Hartono, 2010). Jika pengumuman mengandung informasi (information content), maka diharapkan pasar akan beraksi pada waktu 


\section{NATIONALIY ACCREDVTED JOURNAL - DEECREE NO. 21/E/KRT/2O18}

pengumuman tersebut diterima oleh pasar. Reaksi pasar ditunjukkan dengan adanya perubahan harga dari sekuritas. Reaksi ini dapat diukur dengan menggunakan return sebagai nilai perubahan harga atau dengan menggunakan abnormal return. Jika digunakan abnormal return, maka dapat dikatakan bahwa suatu pengumuman yang mempunyai kandungan informasi akan memberikan abnormal return kepada pasar.

\subsection{Abnormal Return}

Abnormal return adalah return yang didapat investor yang tidak sesuai dengan pengharapan. Abnormal return adalah selisih antara return yang diharapkan dengan return yang didapatkan. Selisih return akan positif jika return yang didapatkan lebih besar dari return yang diharapkan atau return yang dihitung. Sedangkan return akan negatif jika return yang didapat lebih kecil dari return yang diharapkan atau return yang dihitung (Jogiyanto, 2014). Untuk menghitung abnormal return dari saham i pada hari ke $t$ digunakan formula sebagai berikut:

\section{a. Menghitung return sesungguhnya (actual return)}

Perhitungan actual return digunakan selisih harga relative sekarang terhadap harga sebelumnya yang diformulasikan sebagai berikut:

Dimana :

$$
\text { Rit }=\frac{\text { Pit }- \text { Pit }-1}{\text { Pit }-1}
$$

Rit = return realisasi sekuritas ke $-\mathrm{i}$ pada periode ke $\mathrm{t}$

Pit = harga sekuritas sekarang relatif

Pit-1 = harga sekuritas hari sebelumnya

Dalam hal ini harga yang dimaksud adalah harga saham sekuritas ke - i saat penutupan bursa (closing price) pada saat periode ke - $t$.

\section{b. Menghitung return pasar (market return)}

Return pasar dalam hal ini adalah selisih indeks pasar pada periode sekarang dengan indeks pasar pada periode sebelumnya. Dalam hal ini indeks pasar yang dimaksud adalah indeks LQ-45, yang diformulasikan sebagai berikut :

Dimana :

$$
R m t=\frac{\text { Indeks } L Q 45 t-\text { Indeks } L Q 45 t-t}{\text { Indeks } L Q 45 t-1}
$$

Rmt

Indeks LQ45t

$=$ Return pasar periode peristiwa ke-t

Indeks LQ45t-1

= Indeks pasar LQ45 pada period ke-t (sekarang)

= Indeks pasar LQ45 pada periode ke-1 (periode sebelumnya)

\section{c. Menghitung Expected Return}

Expected return adalah return yang diestimasikan dari keuntungan yang diharapkan oleh investor. Dalam penelitian ini digunakan model sesuaian pasar (market adjusted model) dalam mengukur besarnya return ekspektasi. Model ini 
menganggap estimasi return suatu sekuritas adalah return dari indeks pasar. Untuk itu besarnya expected return diformulasikan sebagai berikut :

Dimana :

$$
\mathrm{E}(\mathrm{Rit})=\mathrm{Rmt}
$$

$\mathrm{E}(\mathrm{Rit})=$ Return ekspektasi sekuritas ke-i pada saat periode ke-t Rmt = Return indeks pasar (market return)

d. Menghitung Abnormal Return

Abnormal return dihitung dari selisih antara tingkat keuntungan sebenarnya (actual return) dengan tingkat keuntungan yang diharapkan (expected return), yang dirumuskan sebagai berikut :

Dimana :

$$
\text { ARit }=\text { Rit }-E(\text { Rit })
$$

ARit $=$ Abnormal return saham i pada hari ke $\mathrm{t}$

Rit = Actual return untuk saham i pada hari ke $\mathrm{t}$

E (Rit) = Expected return untuk saham i pada hari ke $\mathrm{t}$

e. Menghitung Average Abnormal Return (ARR)

Pengujian adanya abnormal return umumnya tidak dilakukan untuk setiap sekuritas, tetapi dilakukan secara agregat dengan menguji seluruh ARR sekuritas secara cross-sectional. Menghitung rata-rata abnormal return untuk seluruh saham per hari selama periode peristiwa.

Dimana :

$$
\mathrm{ARR}=\frac{\sum_{i=1}^{n} \text { ARi.t }}{n}
$$

ARit $=$ Abnormal return sekuritas $k e-i$ pada hari ke $\mathrm{t}$

$\mathrm{n}$

$=$ jumlah sekuritas

\subsection{Trading Volume Activity}

Trading Volume Activity merupakan suatu instrumen yang dapat digunakan untuk melihat reaksi pasar modal terhadap informasi melalui parameter pergerakan aktivitas volume perdagangan di pasar modal. Ditinjau dari fungsinya, maka dapat dikatakan bahwa TVA merupakan variasi dari event study. Perbedaan keduanya terletak pada parameter yang digunakan untuk mengukur reaksi pasar terhadap suatu event. TVA merupakan suatu penjumlahan volume dari setiap transaksi perdagangan yang terjadi di bursa saham pada waktu dan saham tertentu, yang diformulasikan sebagai berikut :

$$
\text { TVA } \mathrm{i}, \mathrm{t}=\frac{\sum \text { saham } \text { i yang diperdagangkan pada hari } k e-t}{\sum \text { saham } \text { i yang beredar pada hari } k e-t}
$$

Menghitung rata-rata TVA untuk seluruh saham per hari selama periode peristiwa:

Dimana :

$$
\operatorname{ATV} \mathrm{At}=\frac{\sum_{i=1}^{n} T V A i, t}{n}
$$

TVAit $\quad=$ Trading volume activity sekuritas ke-i pada hari ke-t

$\mathrm{n} \quad=$ jumlah sekuritas 


\section{METODE PENELITIAN}

\subsection{Jenis dan Pendekatan Penelitian}

Penelitian ini merupakan penelitian jenis kuantitatif. Penelitian ini merupakan penelitian studi peristiwa (event study) yang menganalisis adanya reaksi pasar sebagai akibat dari terjadinya peristiwa. Untuk menganalisis pengaruh penetapan undang-undang pengampunan pajak (tax amnesty) terhadap abnormal return dan trading volume activity pada saham-saham LQ-45 di BEI saat terjadinya peristiwa tersebut.

\subsection{Populasi dan Sampel}

Populasi dalam penelitian ini adalah keseluruhan saham yang tercatat dalam LQ-45 periode Juni - Desember pada tahun 2016 yang berjumlah 45 perusahaan yang masuk dalam kategori LQ-45 yang secara aktif diperdagangkan di BEI.

Dalam penelitian ini, teknik pengambilan sampel yang digunakan menggunakan metode purposive sampling. Kriteria yang digunakan untuk memilih sampel dalam penelitian ini antara lain :

1. Masuk dan terdaftar pada kelompok perusahaan LQ-45 periode JuniDesember 2016 karena perusahaan-perusahaan yang masuk dalam LQ-45 merupakan perusahaan dengan tingkat kapitalisasi pasar dan likuiditas yang tinggi di BEI.

2. Tidak melakukan corporate action, seperti right issue, stocksplit, dan sebagainya.

3. Memiliki data yang lengkap selama periode pengamatan yaitu mulai tanggal 20 Juni 2016 sampai tanggal 8 Juli 2016. Penetuan periode pengamatan tersebut merupakan batasan penelitian supaya terfokus pada pengaruh yang timbul akibat adanya pengesahan UU No.11 Tahun 2016 tentang Pengampunan Pajak oleh DPR.

\subsection{Teknik Analisis Data}

\section{Analisis Statistik Deskriptif}

Analisis Statistik Deskriptif dilakukan untuk menentukan nilai minimum, maximum, tingkat rata-rata (mean), dan standar deviasi dari rata-rata abnormal return dan rata-rata trading volume activity selama 10 hari pengamatan.

2. Uji Normalitas

Pengujian normalitas dilakukan untuk mengetahui distribusi data dan menentukan uji statistik yang akan digunakan saat pengujian hipotesis. Apakah menggunakan alat statistic parametric atau non parametrik. Pengujian menggunakan One Sample Kolmogorov-Smirnov Test.

Prosedur yang digunakan yaitu variabel dinyatakan berdistribusi normal apabila Asym sig. (2 tailed) yang diperoleh lebih besar dari derajat keyakinan. Jika nilai signifikansi $>0,05$ maka data berdistribusi normal, sebaliknya jika nilai signifikansi $<0,05$ maka data tidak berdistribusi normal. Jika data tidak 
normal, maka data dapat diubah ke dalam bentuk logaritma atau bentuk lainnya.

3. Uji Beda

Jika data berdistribusi normal, maka digunakan statistic parametric uji $t$ untuk data berpasangan (paired sample $t$-test). Jika data tidak berdistribusi normal, maka digunakan uji non parametric yaitu Wilcoxon Signed Rank Test.

\section{HASIL PENELITIAN DAN PEMBAHASAN}

\subsection{Statistik Deskriptif}

Statistik deskriptif dilakukan untuk melihat rata-rata abnormal return (AAR) dan rata-rata Trading Volume Activity (ATVA) sebelum dan sesudah peristiwa penetapan undang-undang pengampunan pajak (tax amnesty). Hasil rata-rata tersebut dapat dilihat pada tabel berikut :

Tabel 1. Rata-rata Abnormal Return (AAR) dan Rata-rata Trading Volume Activity (ATVA) 5 hari sebelum dan sesudah penetapan UU Tax Amnesty

\begin{tabular}{|c|c|c|c|c|c|c|}
\hline \multicolumn{1}{|c|}{ Descriptive Statistics } \\
\hline AAR_sblm & $\mathrm{N}$ & Minimum & Maximum & Mean & Std. Deviation & Variance \\
AAR_ssdh & 5 & -.0156 & .0152 & -.002560 & .0130519 & .000 \\
ATVA_sblm & 5 & -.0220 & .0070 & -.003200 & .0113446 & .000 \\
ATVA_ssdh & 5 & .0016 & .0026 & .002188 & .0004587 & .000 \\
Valid N (listwise) & 5 & .0014 & .0026 & .002160 & .0004629 & .000 \\
\hline
\end{tabular}

Sumber : Data Sekunder, diolah

Keterangan :

$\mathrm{AAR}=$ Average Abnormal Return

ATVA $=$ Average Trading Volume Activity

Berdasarkan Tabel 1, dapat dilihat perubahan rata-rata abnormal return dan rata-rata trading volume activity 5 hari sebelum dan sesudah penetapan UU tax amnesty. Dari tabel tersebut dapat dilihat sebelum penetapan UU tax amnesty AAR memiliki nilai minimum sebesar -0.0156 dan nilaik maksimum sebesar 0.0152 dengan rata-rata sebesar -0.00256 , sedangkan setelah penetapan UU tax amnesty memiliki nilai minimum sebesar -0.022 dan maksimum sebesar 0.007 dengan ratarata sebesar -0.0032. Variabel ATVA sebelum penetapan UU tax amnesty memiliki nilai minimum 0.0016 dan nilai maksimum 0.0026 dengan nilai rata-rata sebesar 0.002188 , sedangkan nilai ATVA sesudah penetapan UU tax amnesty memiliki nilai minimum sebesar 0.0014 dan nilai maksimum sebesar 0,026 dengan nilai rata-rata sebesar 0.00216 .

\subsection{Uji Normalitas dann Uji Beda}

Uji Normalitas data pada penelitian ini dilakukan dengan Kolmogrov Smirnov test. Hasil analisis dapat dilihat pada tabel berikut. 
Tabel 2. Hasil Uji Kolmogrov Smirnov

One-Sample Kolmogorov-Smirnov Test

\begin{tabular}{|c|c|c|c|}
\hline & & $\begin{array}{c}\text { Average_Abnormal } \\
\text { _Return }\end{array}$ & $\begin{array}{l}\text { Average_Trading } \\
\text { Volume_Activity }\end{array}$ \\
\hline \multicolumn{2}{|l|}{$\mathrm{N}$} & 11 & 11 \\
\hline \multirow{2}{*}{$\begin{array}{l}\text { Normal } \\
\text { Parametersa }\end{array}$} & Mean & .01627555 & .00219629 \\
\hline & Std. Deviation & .054918470 & .000418740 \\
\hline \multirow{3}{*}{$\begin{array}{l}\text { Most Extreme } \\
\text { Differences }\end{array}$} & Absolute & .386 & .220 \\
\hline & Positive & .386 & .159 \\
\hline & Negative & -.254 & -.220 \\
\hline \multicolumn{2}{|c|}{ Kolmogorov-Smirnov Z } & 1.281 & .730 \\
\hline \multicolumn{2}{|c|}{ Asymp.Sig. (2-tailed) } & .075 & .660 \\
\hline
\end{tabular}

Berdasarkan tabel diatas, menunjukan bahwa nilai Asymp. Sig. (2-tailed) untuk ARR dan ATVA masing-masing sebesar 0,075 dan 0,660 yang lebih besar dari tingkat kepercayaan 0,05 sehingga data dapat dinyatakan layak atau berdistribusi normal karena memenuhi asumsi normalitas. Jika data berdistribusi normal, maka digunakan statistic parametric uji t untuk data berpasangan (paired sample t-test).

Tabel 3. Hasil Uji Paired Sample t-Test Rata-rata Abnormal Return (AAR) sebelum dan sesudah penetapan UU Tax Amnesty

\begin{tabular}{|c|c|c|c|c|c|c|c|c|}
\hline \multicolumn{9}{|c|}{ Paired Samples Test } \\
\hline & \multicolumn{5}{|c|}{ Paired Differences } & $\mathrm{T}$ & $\mathrm{df}$ & $\begin{array}{l}\text { Sig. (2- } \\
\text { tailed) }\end{array}$ \\
\hline & \multirow[b]{2}{*}{ Mean } & \multirow{2}{*}{$\begin{array}{c}\text { Std. } \\
\text { Deviation }\end{array}$} & \multirow{2}{*}{$\begin{array}{l}\text { Std. Error } \\
\text { Mean }\end{array}$} & \multicolumn{2}{|c|}{$\begin{array}{c}95 \% \text { Confidence Interval } \\
\text { of the Difference }\end{array}$} & & & \\
\hline & & & & Lower & Upper & & & \\
\hline $\begin{array}{c}\text { Pair } 1 \text { AAR_sblm - } \\
\text { AAR_ssdh }\end{array}$ & .0006400 & .0099991 & .0044718 & -.0117756 & .0130556 & .143 & 4 & .893 \\
\hline
\end{tabular}

Sumber : Data Sekunder, diolah

Keterangan :

\section{$\mathrm{AAR}=$ Average Abnormal Return}

Dari tabel diatas dapat di simpulkan bahwa tidak terdapat perbedaan yang signifikan antara AAR sebelum dan AAR sesudah peristiwa, hal ini dibuktikan dengan nilai Sig. (2-tailed) sebesar 0,893 lebih besar dari 0,05 (taraf signifikansi) sehingga hipotesis pertama (H1) ditolak. Artinya bahwa tidak terjadi perbedaan yang signifikan antara AAR sebelum dan AAR sesudah penerapan UU pengampunan pajak (tax amnesty). 
Tabel 4. Hasil Uji Paired Sample t-Test Rata-rata Trading Volume Activity (ATVA) sebelum dan sesudah penetapan UU Tax Amnesty

Paired Samples Test

\begin{tabular}{|c|c|c|c|c|c|c|c|c|}
\hline & \multicolumn{5}{|c|}{ Paired Differences } & $\mathrm{t}$ & $\mathrm{df}$ & $\begin{array}{l}\text { Sig. (2- } \\
\text { tailed) }\end{array}$ \\
\hline & \multirow[b]{2}{*}{ Mean } & \multirow{2}{*}{$\begin{array}{c}\text { Std. } \\
\text { Deviation }\end{array}$} & \multirow{2}{*}{$\begin{array}{c}\text { Std. Error } \\
\text { Mean }\end{array}$} & \multicolumn{2}{|c|}{$\begin{array}{c}95 \% \text { Confidence Interval } \\
\text { of the Difference }\end{array}$} & & & \\
\hline & & & & Lower & Upper & & & \\
\hline $\begin{aligned} \text { Pair } 1 & \text { ATVA_sblm - } \\
& \text { ATVA_ssdh }\end{aligned}$ & .0000280 & .0006219 & .0002781 & -.0007442 & .0008002 & .101 & 4 & .925 \\
\hline
\end{tabular}

Sumber : Data Sekunder, diolah

Keterangan :

ATVA = Average Trading Volume Activity

Dari tabel diatas dapat di simpulkan bahwa tidak terdapat perbedaan yang signifikan antara ATVA sebelum dan ATVA sesudah peristiwa, hal ini dibuktikan dengan nilai Sig. (2-tailed) sebesar 0,925 lebih besar dari 0,05 (taraf signifikansi) sehingga hipotesis kedua $(\mathrm{H} 2)$ ditolak. Artinya bahwa tidak terjadi perbedaan yang signifikan antara ATVA sebelum dan ATVA sesudah penerapan UU pengampunan pajak (tax amnesty).

\subsection{Pembahasan}

\subsubsection{Terdapat perbedaan yang signifikan average abnormal return (AAR) sebelum dan setelah penetapan UU Tax Amnesty.}

Hasil pengujian pada penelitian menunjukkan nilai t-hitung sebesar 0,143 dan nilai Sig. (2-tailed) sebesar 0,893 lebih besar dari 0,05 (taraf signifikansi) sehingga hipotesis pertama (H1) ditolak artinya tidak terdapat perbedaan average abnormal return (AAR) pada LQ-45 di Bursa Efek Indonesia pada saat sebelum dan sesudah peristiwa pengumuman UU pengampunan pajak periode pertama resmi berlaku.

Teori sinyal mengatakan bahwa suatu informasi dapat ditangkap sebagai sinyal positif, sinyal negatif, dan tidak berdampak sama sekali untuk mempengaruhi keputusan investor (Manik et al,2017). Dari data tersebut dapat dianalisa bahwa informasi pengampunan pajak yang masuk ke pasar modal masih kurang sehingga belum meberikan sinyal positif maupun sinyal negatif kepada investor dalam melakukan reaksi yang mampu membuat perbedaan harga saham pada perusahaan LQ-45 yang tercatat di Bursa Efek Indonesia yang diukur dari average abnormal return.

Indeks LQ-45 menunjukkan pertumbuhan tetapi belum mampu memberikan perbedaan harga saham di Bursa Efek Indonesia yang diukur dari average abnormal return pada saat sebelum dan sesudah peritiwa penetapan undang-undang pengampunan pajak. Peningkatan yang terjadi hanya bersifat sementara dan tidak berkepanjangan. Investor cenderung menahan keputusan untuk berinvestasi karena menganalis informasi sebelum mengambil keputusan. Karena dapat 


\section{NATIONALLY ACCREDITED JOURNAL - DEECREE NO. 21/E//KPT/2O18}

disebabkan investor telah mengetahui bahwa kebijakan pengampunan pajak dilakukan dalam 3 (tiga) periode sehingga investor ingin melihat hasil dari repatriasi asset para wajib pajak yang diterima sudah sesuai dengan target yang telah ditetapkan oleh pemerintah. Mutaqin (2013) mengatakan bahwa Indonesia telah dua kali mengadakan pengampunan pajak tetapi penerapannya tidak berhasil sebagaimana yang diharapkan.

Hasil pengujian ini menunjukkan bahwa informasi penetapan UU pengampunan pajak tidak berdampak bagi investor pada saat sebelum dan sesudah peristiwa pengesahan UU pengampunan pajak periode pertama sehingga belum mampu membuat perbedaan harga saham di pasar modal khususnya LQ-45 yang tercatat di Bursa Efek Indonesia. Hasil pengujian hipotesis ini sejalan dengan apa yang diteliti oleh (Rahayu, 2016) yang mengatakan bahwa tidak terdapat reaksi harga saham pada Jakarta Islamic Index (JII) yang signifikan saat peritiwa sebelum dan sesudah tax amnesty periode pertama resmi diberlakukan. Hasil pengujian hipotesis ini juga sejalan dengan apa yang diteliti oleh Manik, Sondakh, \& Rondonuwu, (2017) yang mengatakan bahwa tidak terdapat reaksi harga saham pada saham sektor properti pada Bursa Efek Indonesia yang signifikan saat peritiwa sebelum dan sesudah tax amnesty periode pertama resmi diberlakukan.

\subsubsection{Terdapat perbedaan yang signifikan average trading volume activity (ATVA) sebelum dan setelah penetapan UU Tax Amnesty.}

Hasil pengujian pada penelitian menunjukkan nilai t-hitung sebesar 0,101 dan nilai Sig. (2-tailed) sebesar 0,925 lebih besar dari 0,05 (taraf signifikansi) sehingga hipotesis kedua (H2) ditolak artinya tidak terdapat perbedaan trading volume activity pada perusahaan LQ-45 di Bursa Efek Indonesia pada saat sebelum dan sesudah peristiwa pengumuman UU pengampunan pajak periode pertama resmi berlaku.

Perubahan rata-rata trading volume activity tersebut belum mampu menunjukkan apakah informasi yang terkandung pada peristiwa penetapan undang-undang tax amnesty tersebut adalah informasi yang dianggap sebagai sinyal positif (good news) atau negatif (bad news) sehingga investor lebih berhati-hati dalam melakukan transaksi pada pasar modal. Hal ini dapat dilihat melalui perubahan nilai trading volume activity sebelum dan setelah penetapan undangundang tax amnesty. Walaupun terjadi perubahan tersebut, tapi informasi yang terkandung pada peristiwa tersebut tidak cukup untuk menimbulkan perbedaan rata-rata trading volume activity sebelum dan setelah peristiwa.

Hasil penelitian ini sejalan dengan penelitian yang dilakukan oleh Rahayu (2016) tentang tax amnesty yang menyatakan tidak terdapat perbedaan yang signifikan terkait dengan trading volume activity (TVA) pada saham - saham syariah. Nugroho (2013) menganalisa reaksi pasar saham terkait trading volume activity dengan peristiwa tsunami Jepang 2011 bahwa aktivitas volume perdagangan tidak ditemukan perbedaan sebelum dan sesudah peristiwa pada saham - saham LQ-45 di Indonesia. Saragih (2011) menyatakan tidak ada perbedaan volume perdagangan 
sebelum dan sesudah peristiwa rekomendasi DPR kepada pemerintah atas kasus century.

\subsection{Kesimpulan}

\section{KESIMPULAN DAN SARAN}

Berdasarkan hasil penelitian data dan uji statistik yang telah dilakukan, maka dapat diperoleh kesimpulan :

1. Peristiwa pengampunan pajak tidak memiliki kandungan informasi bagi investor, ditunjukkan tidak adanya perbedaan average abnormal return (AAR) yang signifikan selama periode sebelum dan setelah peristiwa UU tax amnesty.

2. Hasil analisis terhadap average trading volume activity (ATVA) yang tidak terdapat perbedaan yang signifikan selama periode sebelum dan setelah peristiwa penetapan UU tax amnesty.

\subsection{Saran}

Saran untuk penelitian selanjutnya yaitu sebagai berikut:

1. Informasi yang terdapat dalam pasar modal merupakan informasi yang berharga, terlebih dengan informasi yang juga beredar di media massa untuk digunakan sebagai pertimbangan keputusan. Sehingga diharapkan investor dapat memperoleh abnormal return yang positif atas suatu peristiwa karena mengikuti isu yang beredar seperti isu politik, stabilitas perekonomian dan lainnya.

2. Bagi peneliti selanjutnya diharapkan dapat mengembangkan model penelitian dengan melibatkan variabel atau peristiwa kondisional terkini.

\section{DAFTAR PUSTAKA}

Gesit,Bangun S. 2016. "Reaksi Pasar Saham Industri Propertu dan Real Estate Terhadap Penetapan Peraturan Bank Indonesia tentang Rasio Loan To Valuer atau Financing To Value (PBI No.17/10/PBI/2015)". Magister Manajemen Universitas Gajah Mada, Yogyakarta.

Hartono, J. (2010). Teori Portofolio dan Analisis Investasi (Edisi Sepuluh). Yogyakarta: BPFE.

Jogiyanto. (2014). Teori Portofolio dan Analisis Investasi, Yogyakarta: BPFE-UGM. SSRN Electronic Journal.

Manik, S., Sondakh, J., \& Rondonuwu, S. (2017). Analisis Reaksi Harga Saham Sebelum Dan Sesudah Tax Amnesty Periode Pertama (Studi Kasus Saham Sektor Properti Yang Tercatat Di Bursa Efek Indonesia). Jurnal Riset Ekonomi, Manajemen, Bisnis Dan Akuntansi. https://doi.org/10.35794/emba.v5i2.15989

Mutaqqin, Zaenal. 2013. "Tax Amnesty di Indonesia”. Refika Aditama. Bandung. Pajak,go.id, 2016. Refleksi Tingkat Kepatuhan Wajib Pajak. http://www.pajak.go.id. 
Nugroho,Handy. 2013. “The Impact of Japan Tsunami Disaster on Indonesian Stock Market : an Event Study". Magister Manajemen Universitas Gajah Mada. Yogyakarta.

Rachman, Ari. 2013. "Pemilihan Umum Presiden 2009 dan return Saham PerusahaanPerusahaan Terbuka di Bursa Efek Indonesia". Magister Manajemen Universitas Gajah Mada. Yogyakarta.

Rahayu,Dwi. 2016. “Analisis Reaksi Pasar Modal Terhadap Kebijakan Amnesty Pajak (Studi Kasus pada Saham-Saham Syariah yang Masuk Daftar JII Periode JuniNovember 2016)". Magister Ekonomi UIN. Yogyakarta.

Saragih,Immanuel Daomara. 2011. "Pengaruh Rekomendasi DPR atas Kasus Century Terhadap Pergerakan Saham Industri Keuangan (Studi Kasus pada BEI)". Magister Manajemen Universitas Gajah Mada. Yogyakarta.

Sirait, R. S., Tiswiyanti, W., \& Mansur, F. (2012). Dampak Pergantian Menteri Keuangan RI tahun 2010 terhadap Abnormal Return Perusahaan Perbankan yang terdaftar di BEI. Binar Akuntansi.

Wardhani,Laksmi Swastika. 2012. "Reaksi Pasar Modal Indonesia Terhadap Peristiwa Pemilihan Gubernur DKI Jakarta Putaran II 2012 (Event Study pada Saham Anggota Indeks Kompas 100)". Magister Manajemen Universitas Brawijaya. Malang.

Widihartanto, Sekti, PhD dan Herru Widiatmanti SE, ME. (2016) “Tax Amnesty dan Faktor Penentu Kenerhasilannya; Pelajaran dari Beberapa Otoritas Pajak. DDTC Working Paper. No. 1415

www.bps.go.id

www.idx.co.id

www.pajak.go.id 